\title{
Spawanie staliwa Cr-Mo z dodatkiem pierwiastków ziem rzadkich metodą TIG
}

\author{
Welding of Cr-Mo cast steel \\ with rare earth elements using the TIG welding process
}

\section{Streszczenie}

W pracy przedstawiono efekty spawania złączy próbnych wykonanych metodą TIG ze staliwa G17CrMo5-5 przeznaczonego do pracy w podwyższonych temperaturach. Wykonano złącza próbne na dwóch seriach wytopów tj. niemodyfikowanego oraz z dodatkiem metali ziem rzadkich (MZR). Modyfikację staliwa prowadzono przy użyciu mieszanki cerowej w postaci mischmetalu. Autorzy opisują technologię spawania złączy próbnych metodą TIG. W celu określenia jakości wykonanych połączeń przeprowadzono obserwacje makroskopowe złączy na przekroju poprzecznym. Dokonano pomiarów rozkładu twardości oraz obserwacje mikroskopowe wybranych obszarów złączy. Autorzy wykazali różnice we własnościach pomiędzy staliwem niemodyfikowanym a modyfikowanym.

Słowa kluczowe: staliwo; spawanie TIG; twardość

\begin{abstract}
The paper shows the effect of the welding test welded joints made of TIG welding process of G17CrMo5-5 cast steel designed to operate at elevated temperatures. The test welded joints were made on two sets of melt that are unmodified and with rare earth metals (MZR). Modification of cast steel was performed using mischmetal cerium mixture. The authors describe the technology of welding process with the TIG method. To determine the quality of the connections carried out macroscopic observation of joints in cross-section. Hardness distribution measurements and microscopic observations of selected joint areas were performed. The authors showed differences in properties between unmodified and modified cast steel.
\end{abstract}

Keywords: cast steel; TIG welding process; hardness

\section{Wstęp}

Staliwa z dodatkiem chromu i molibdenu są szeroko stosowane w energetyce do pracy w podwyższonych temperaturach. Staliwo G17CrMo5-5 wykorzystywane jest na odlewy kadłubów oraz pokrywy zaworów przeznaczonych do zabudowy $w$ instalacjach rurociągowych przewodzących nieagresywne i nietoksyczne czynniki robocze. Montaż zaworu na instalacji odbywa się przy użyciu przyłączy z gwintem lub poprzez wykonanie złączy spawanych (rys. 1) [1]. Zagadnienie to jest również istotne $w$ aspekcie naprawy wad odlewniczych lub remontów korpusów zaworów czy turbin po długim czasie eksploatacji, lub w sytuacji uszkodzeń awaryjnych [2].

Najczęściej przyłącza ze staliwa G17CrMo5-5 spawa się głównie elektrodami otulonymi (111) lub w osłonie gazów ochronnych metodą TIG (141). Stosuje się materiały dodatkowe o składzie chemicznym stopiwa odpowiadającym składowi materiału podstawowego [3].

Zagadnienie spawania odlewów staliwnych jest o tyle trudne, że należy brać pod uwagę wady, jakie mogą wystąpić w stanie lanym tj. mikrorzadzizny, pęknięcia, pęcherze itp.

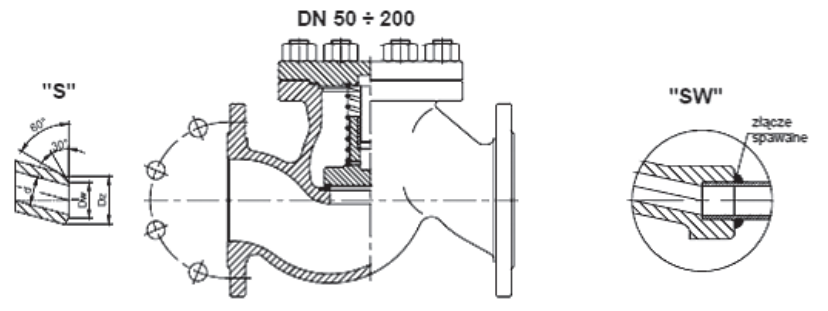

Rys. 1. Przykładowy zawór zwrotny z przyłączem spawanym [1] Fig. 1. An example of a check valve with welded connection [1]

co może wpływać na jakość wykonanych złączy. Istotna jest również geometria spawanego elementu oraz grubości ścianek. Często, aby przeprowadzić poprawny proces spawania uwzględnia się zabiegi obróbki cieplnej. W przypadku złączy wykonanych z odlewami ze staliwa G17CrMo5-5 stosuje się wyżarzanie w temperaturze ok. $700{ }^{\circ} \mathrm{C}$ [4]. Nagrzewanie prowadzi się poprzez zastosowanie palników, nagrzewnic oporowych lub indukcyjnych. Zastosowanie obróbki cieplnej ma na celu uzyskanie odpowiedniej struktury złącza oraz usunięcie naprężeń zazwyczaj po przekroczeniu pewnej grubości.

Dr inż. Andrzej Skrzypczyk, dr inż. Justyna Kasińska - Politechnika Świętokrzyska w Kielcach.

Autor korespondencyjny/Corresponding author: kasinska@tu.kielce.pl 
Tablica I. Skład chemiczny staliwa G17CrMo5-5

Table I. Chemical composition of G17CrMo5-5 cast steel

\begin{tabular}{|c|c|c|c|c|c|c|c|c|c|c|}
\hline $\begin{array}{l}\text { Pierwiastek } \\
\text { [\% mas] }\end{array}$ & C & Si & Mn & $\mathbf{P}$ & $S$ & $\mathrm{Cr}$ & Mo & $\mathrm{Ni}$ & Al & MZR \\
\hline $\begin{array}{l}\text { Przed odtlenianiem } \\
\text { i dodaniem MZR }\end{array}$ & 0,17 & 0,28 & 0,57 & 0,024 & 0,016 & 1,13 & 0,54 & 0,11 & 0,004 & - \\
\hline $\begin{array}{l}\text { Po odtlenianiu } \\
\text { i dodaniu MZR }\end{array}$ & 0,16 & 0,37 & 0,62 & 0,022 & 0,013 & 1,22 & 0,53 & 0,12 & 0,050 & $<0,01$ \\
\hline
\end{tabular}

\section{Materiał do badań}

Do badań wykorzystano próbki ze staliwa G17CrMo5-5 niemodyfikowanego oraz z dodatkiem metali ziem rzadkich. Do modyfikacji użyto mieszankę cerową w postaci mischmetalu $(49,8 \% \mathrm{Ce}, 21,8 \% \mathrm{La}, 17,1 \% \mathrm{Nd}, 5,5 \% \mathrm{Pr}$, $5,35 \%$ reszta MZR). Analizy składu chemicznego wykonano po końcowym odtlenianiu aluminium na próbkach pobranych z wlewków próbnych. Zawartość tlenu, węgla i siarki określono w analizatorze LECO z wykorzystaniem systemu detekcji podczerwieni. Zawartość pozostałych pierwiastków określono w analizatorze ARL metodą atomowej spektrometrii emisyjnej. Wyniki analizy składu chemicznego przedstawiono w tablicy I. Próbki pobrane z wlewków próbnych poddano obróbce cieplnej tj. wyżarzaniu normalizującemu (940 ${ }^{\circ} \mathrm{C} / 1 \mathrm{~h} /$ pow.) oraz odpuszczaniu $\left(710^{\circ} \mathrm{C} / 2 \mathrm{~h} /\right.$ pow.).

Modyfikacja staliwa G17CrMo5-5 miszmetalem metalu spowodowała zmianę granicy plastyczności i wytrzymałości na rozciąganie (tabl. II). Wartość granicy plastyczności zwiększa się o $44 \mathrm{MPa}$, a wytrzymałości na rozciąganie o $24 \mathrm{MPa}$, przy czym wartości wydłużenia i przewężenia pozostają praktycznie niezmienione. Szczególnie istotna jest zmiana udarności, która wzrasta z 30 do $99 \mathrm{~J} / \mathrm{cm}^{2}$ $[5,6]$. Badania prowadzone były w temperaturze otoczenia. Zmiany opisane powyżej mogą wpłynąć na właściwości wykonanych połączeń spawanych.

Tablica II. Właściwości mechaniczne staliwa G17CrMo5-5 Table II. Mechanical properties of G17CrMo5-5 cast steel

\begin{tabular}{|c|c|c|c|c|c|}
\hline & $\begin{array}{c}\mathbf{R}_{\mathbf{e}} \\
{[\mathrm{MPa}]}\end{array}$ & $\begin{array}{c}\mathbf{R}_{\mathbf{m}} \\
{[\mathrm{MPa}]}\end{array}$ & $\begin{array}{c}\mathbf{A}_{5} \\
{[\%]}\end{array}$ & $\begin{array}{c}\mathbf{Z} \\
{[\%]}\end{array}$ & $\begin{array}{c}\mathbf{K V} \\
{\left[\mathbf{J} / \mathrm{cm}^{2}\right]}\end{array}$ \\
\hline G17CrM05-5 & 507,4 & 661 & 20,08 & 63,6 & 30 \\
\hline $\begin{array}{c}\text { G17CrMo5-5 } \\
\text { Z dodatkiem } \\
\text { MZR }\end{array}$ & 551,4 & 685,2 & 19,92 & 62,4 & 99 \\
\hline
\end{tabular}

\section{Wykonanie złączy próbnych}

Z próbek przygotowanych ze staliwa G17CrMo5-5 wykonano doczołowe złącza próbne $w$ stanie płaskim o wymiarach 200 x 84 x 12 mm. Do spawania złączy próbnych zastosowano ręczne spawanie metodą TIG. Widok lica (fragment) jednego z wykonanych złączy próbnych pokazano na rysunku 2.

W charakterze spawalniczych materiałów dodatkowych zastosowano drut lity w gatunku LNT/LNM-19 [7] oraz argon jako gaz osłonowy [8]. Spawanie metodą TIG realizowano jako wielowarstwowe dwustronne. Na rysunku 3 pokazano sposób przygotowania brzegów do spawania.

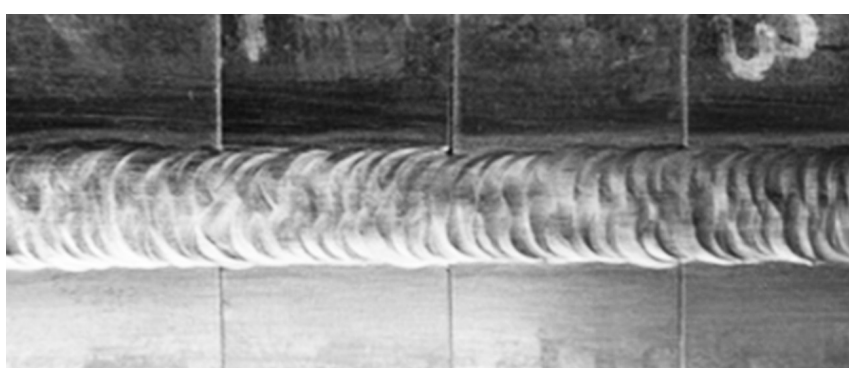

Rys. 2. Widok lica spoiny złącza doczołowego ze staliwa G17CrMo 5-5 Fig. 2. View of butt joint of G17CrMo 5-5 cast steel

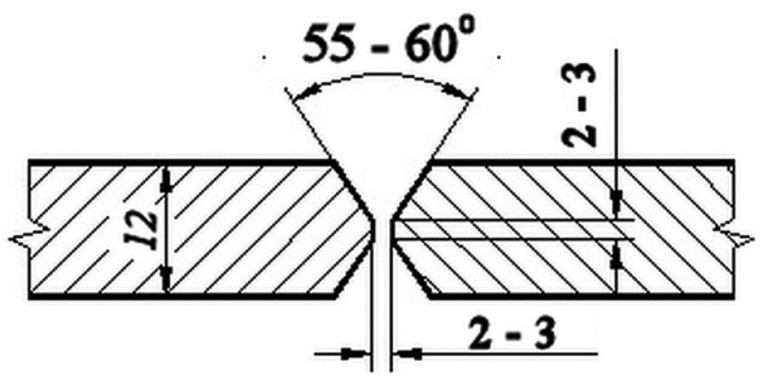

Rys. 3. Rozwiązanie konstrukcyjne rowka spawalniczego

Fig. 3. Constructional solution of the welding groove

Rysunek 4 przedstawia sposób wykonania spoiny (sposób rozmieszczenia poszczególnych ściegów i warstw oraz kolejność ich wykonania). W tablicy III ujęto podstawowe parametry technologiczne wykonania złączy spawanych. Złącza próbne wykonano w pozycji podolnej - PA.

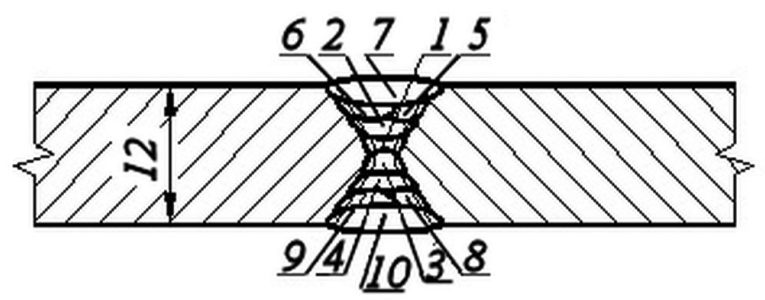

Rys. 4. Sposób wykonania spoiny

Fig. 4. A method for making joint

\section{Wyniki badań}

\section{Obserwacje makroskopowe}

Zdjęcia wykonano przy użyciu mikroskopu AZ100 Multizoom firmy NIKON oraz w mikroskopie skaningowym JSM 7100F. Już wstępne obserwacje wskazują na brak niezgodności spawalniczych co świadczy o poprawności przeprowadzonego procesu spawania (rys. 5a, 5c). Obserwacje makroskopowe z obszarów spoina - linia wtopienia - strefa wpływu ciepła potwierdziły prawidłową budowę złączy 
Tablica III. Parametry technologiczne wykonania złączy próbnych

Table III. Technological parameters of performance test joints

\begin{tabular}{|c|c|c|c|c|c|c|}
\hline $\begin{array}{c}\text { Nr } \\
\text { ściegu }\end{array}$ & $\begin{array}{c}\text { Metoda } \\
\text { spawania }\end{array}$ & $\begin{array}{c}\text { Średnica } \\
\text { spoiwa } \\
{[\mathrm{mm}]}\end{array}$ & $\begin{array}{c}\text { Natężenie } \\
\text { prądu } \\
{[\mathrm{A}]}\end{array}$ & $\begin{array}{c}\text { Napięcie } \\
\text { łuku } \\
{[\mathrm{V}]}\end{array}$ & $\begin{array}{c}\text { Prędkość } \\
\text { spawania } \\
{[\mathbf{c m} / \mathbf{m i n}]}\end{array}$ & $\begin{array}{c}\text { Przepływ } \\
\text { gazu osłonowego } \\
{[\mathbf{l} \text { min] }}\end{array}$ \\
\hline 1,3 & 141 & $\Phi=2,0$ & 100 & 11,3 & $25 \div 30$ & $8,0 \div 10,0$ \\
\hline 2,4 & 141 & $\Phi=2,4$ & 120 & 11,9 & $20 \div 25$ & 12,0 \\
\hline $5 \div 10$ & 141 & $\Phi=2,4$ & 130 & 13,2 & $20 \div 25$ & 12,0 \\
\hline
\end{tabular}

Temperatura podgrzewania: $100\left[{ }^{\circ} \mathrm{C}\right]$, temperatura międzyściegowa: $200 \div 230\left[{ }^{\circ} \mathrm{C}\right]$, wyżarzanie $710\left[{ }^{\circ} \mathrm{C}\right]$
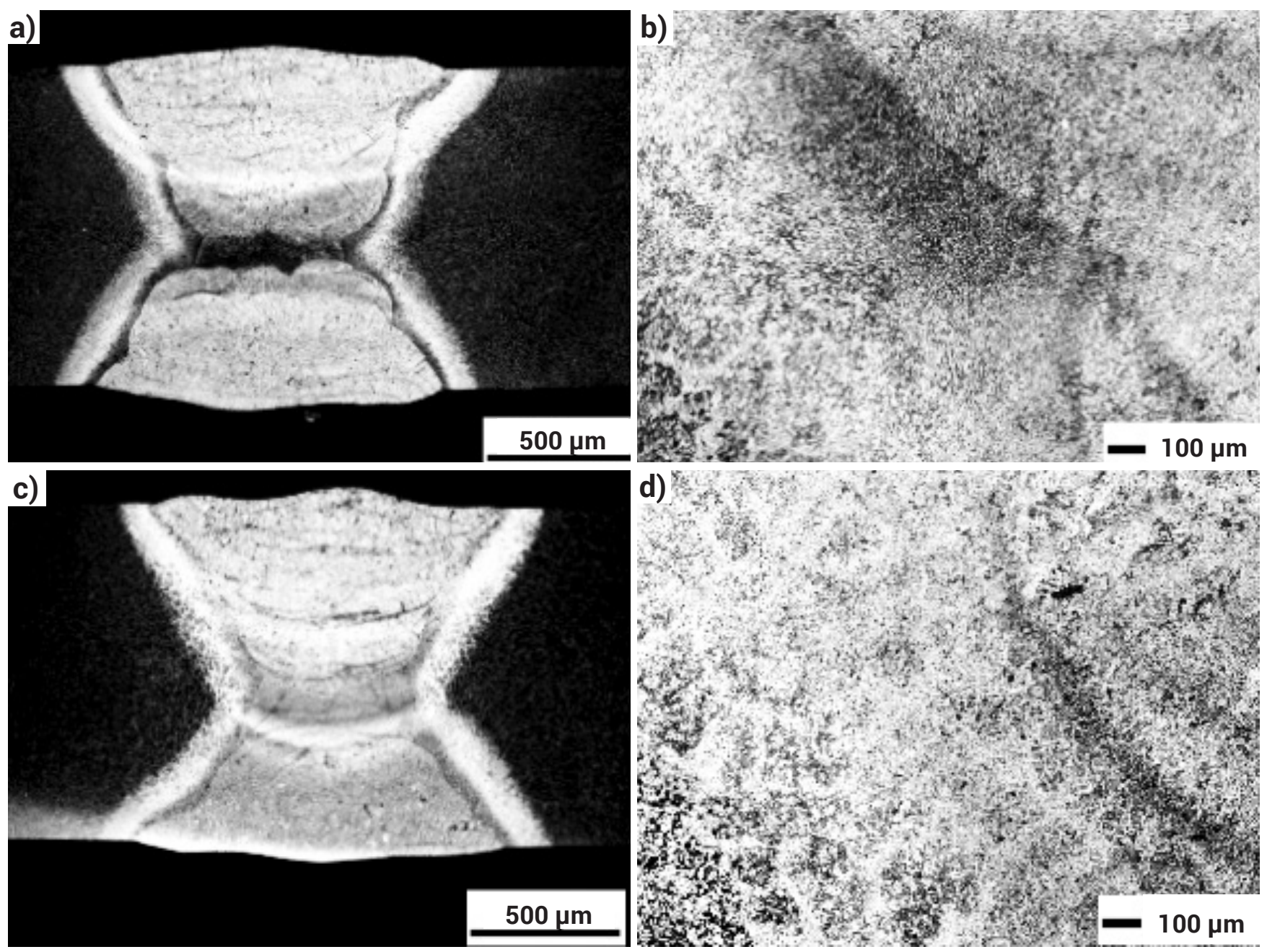

Rys. 5. Makrostruktura próbnych złączy spawanych ze staliwa G17CrMo5-5: a), b) staliwo niemodyfikowane; c), d) staliwo z dodatkiem MZR Fig. 5. Macrostructure of weldet joints made of G17CrMo5-5 cast steel: a),b) non-modified cast steel; c),d) modified cast steel

spawanych na przekroju poprzecznym z poprawnym wtopieniem w materiał rodzimy (rys. 5b, 5d). W obu przypadkach złącza charakteryzują się wąską strefą wpływu ciepła (od 1,5 do 2,4 mm) typową dla spawania metodą TIG oraz stosunkowo płaskim licem z łagodnym przejściem do łączonych brzegów.

\section{Pomiary twardości i badania udarności}

Badania twardości [9] na przekroju poprzecznym złączy pokazano na rysunkach 6 i 7. W przypadku złączy próbnych ze staliwa bez dodatków pierwiastków ziem rzadkich zauważalny jest spadek twardości w środku spoiny. Znaczna różnica twardości występuje pomiędzy materiałem rodzimym (MR) a strefą wpływu ciepła (SWC). Wyżarzanie złączy po spawaniu w temperaturze $710^{\circ} \mathrm{C}$ nie zmieniło charakteru rozkładu twardości złączy oraz nie doszło do istotnych zmian ich wartości. Jedynie zaobserwowano ujednolicenie rozkładu twardości dla wszystkich obszarów złączy tj. obu lic oraz osi spoiny.

Badania udarności połączeń spawanych wykonano zgodnie z normą ISO 9016:2012 [11] na próbkach udarnościowych z karbem naciętym w osi spoiny (próbki typu VWT) oraz w SWC (próbki typu VHT). W obszarze spoiny dla obu rodzajów złączy (ze staliwa niemodyfikowanego oraz z dodatkiem MZR) uzyskano podobne wyniki udarności tj. kolejno 48,7 i 45,6 [J/ $\left.\mathrm{cm}^{2}\right]$. Wzrost udarności odnotowano w SWC złączy ze staliwa z dodatkiem MZR, która wyniosła $78,5 \mathrm{~J} / \mathrm{cm}^{2}$, przy wartości dla staliwa niemodyfikowanego $44,4 \mathrm{~J} / \mathrm{cm}^{2}$. 


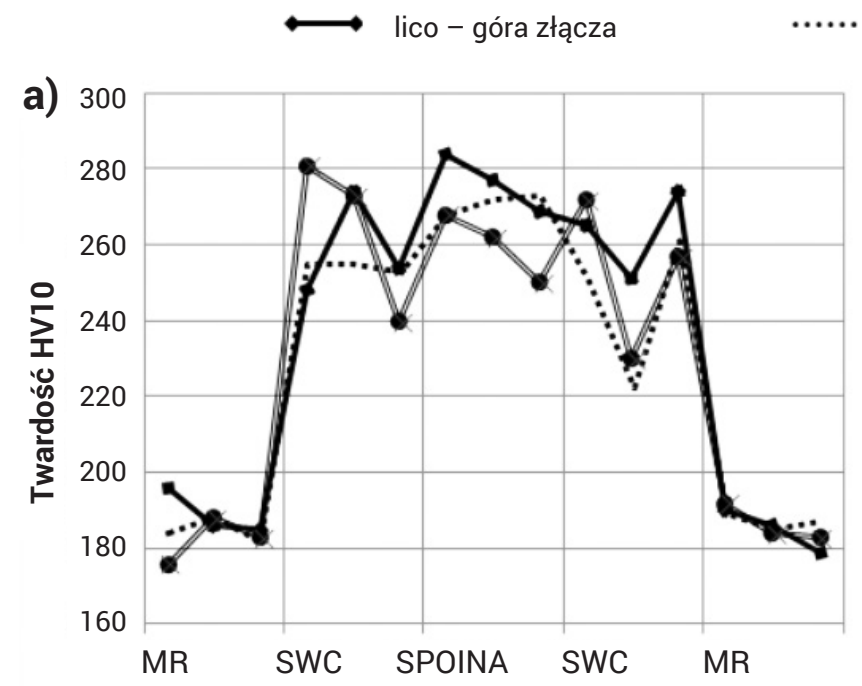

ś złącza

$\bullet$ lico - dół złącza

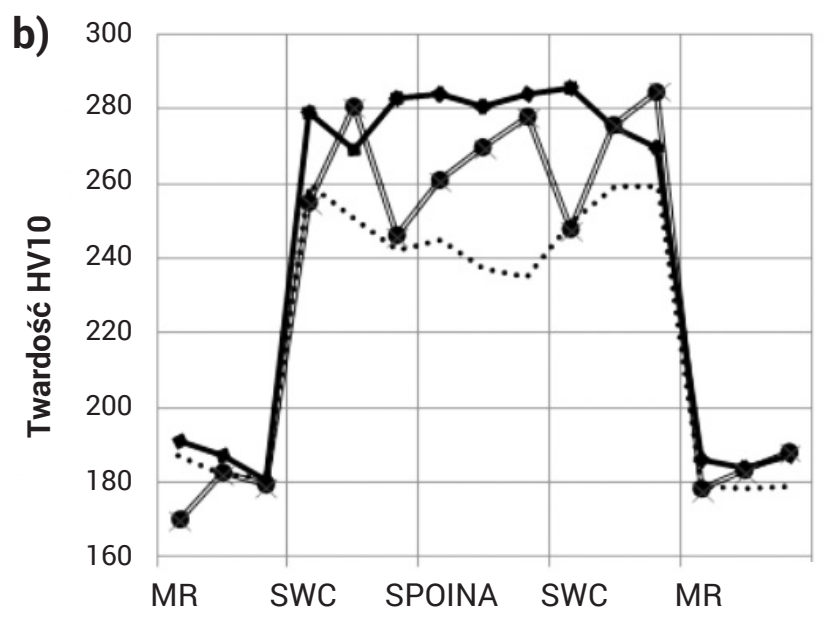

Rys. 6. Rozkład twardości HV10 złączy: a) złącze ze staliwa niemodyfikowanego, b) złącze ze staliwa z dodatkiem MZR

Fig. 6. HV 10 hardness distributions of joints: a) welded joint of non-modified cast steel, b) welded joint of modified cast steel

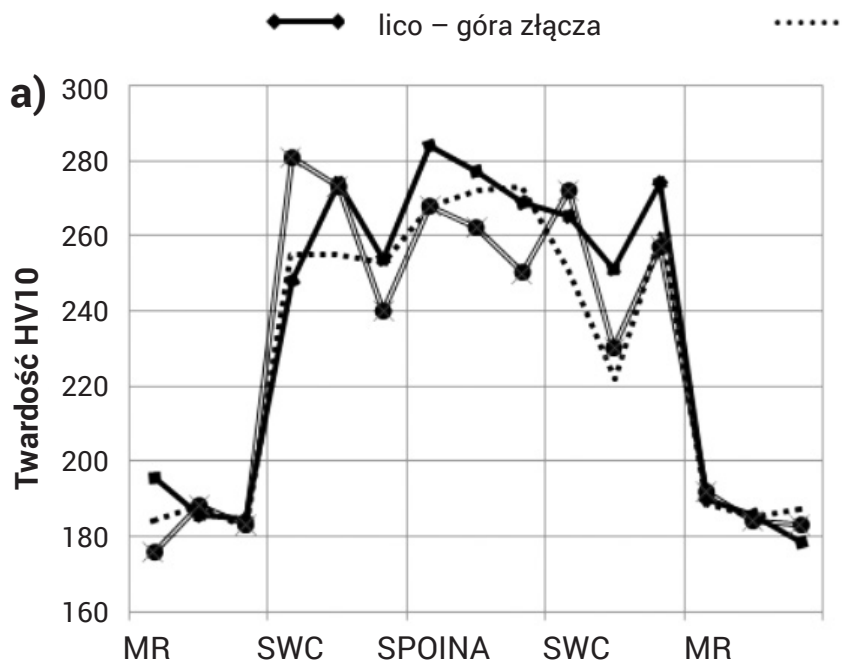
oś złącza

$\bullet$ lico - dół złącza

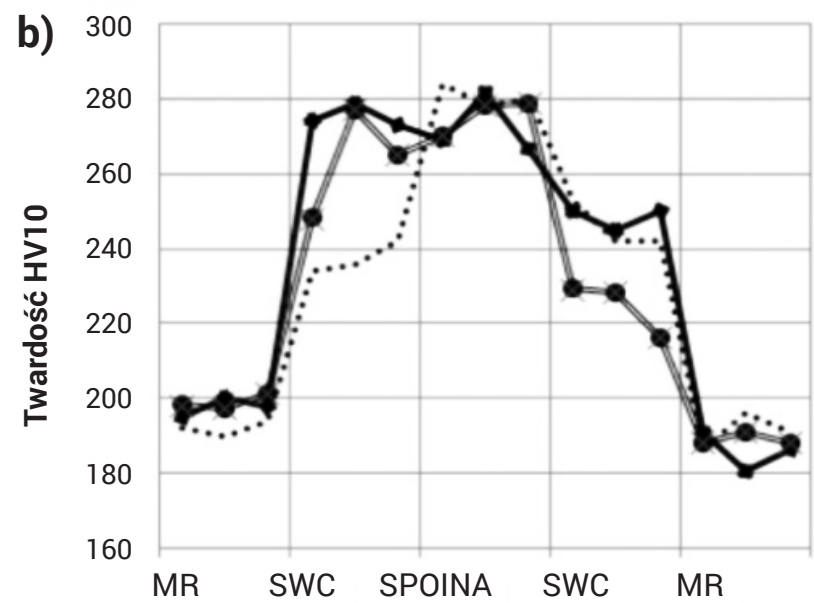

Rys. 7. Rozkład twardości HV10 złączy wyżarzanych: a) złącze ze staliwa niemodyfikowanego, b) złącze ze staliwa z dodatkiem MZR Fig. 7. HV 10 hardness distributions of annealed joints: a) welded joint of non-modified cast steel, b) welded joint of modified cast steel

\section{Struktura złączy spawanych}

Obserwacje mikrostruktury materiału rodzimego wykazały, że wprowadzenie mieszanki cerowej wpływa na zmniejszenie wielkości ziarna oraz na procesy wydzieleniowe (rys. 8) [5,6]. W mikrostrukturze staliwa modyfikowanego doszło do utworzenia się bardziej równomiernej struktury bainitycznej z lokalnie występującymi ziarnami ferrytu o mniejszych rozmiarach. Obserwacja mikrostruktury nie pokazuje różnic w poszczególnych strefach złączy dla staliwa modyfikowanego oraz niemodyfikowanego. Jak widać na rysunku 9 podczas badań mikrostruktury przy powiększeniach x5000 ujawniają się różnice w poszczególnych obszarach złączy. Jest to również efektem zastosowanej modyfikacji. Wprowadzenie metali ziem rzadkich spowodowało zmianę morfologii wtrąceń niemetalicznych oraz doszło do zwiększenia dyspersji faz wtórnych w osnowie staliwa modyfikowanego.

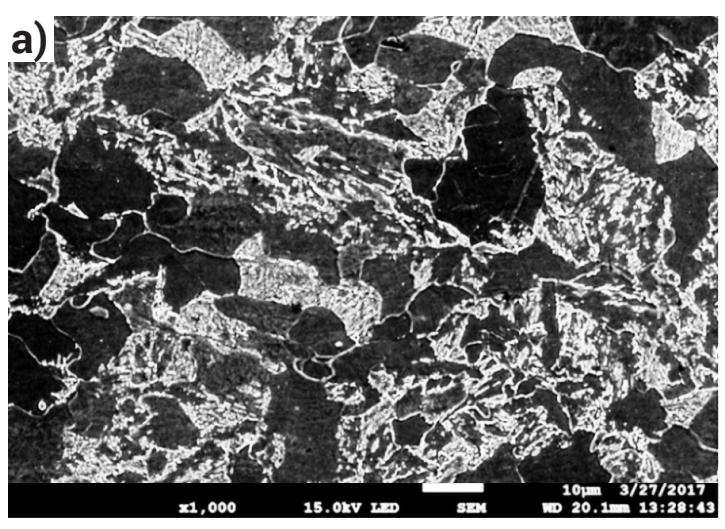

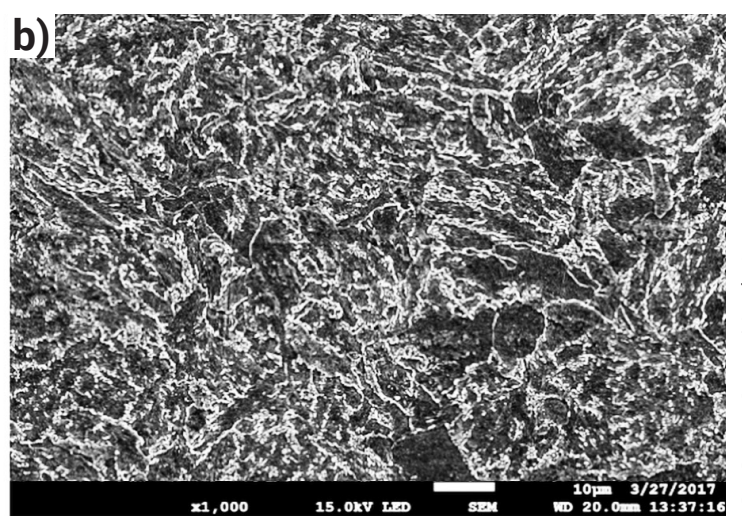

Rys. 8. Mikrostruktura staliwa G17CrM05-5: a) staliwo niemodyfikowane, b) staliwo $z$ dodatkiem MZR Fig. 8. Microstructure of G17CrMo5-5 cast steel: a) non-modified cast steel, b) modified cast steel 
staliwo niemodyfikowane

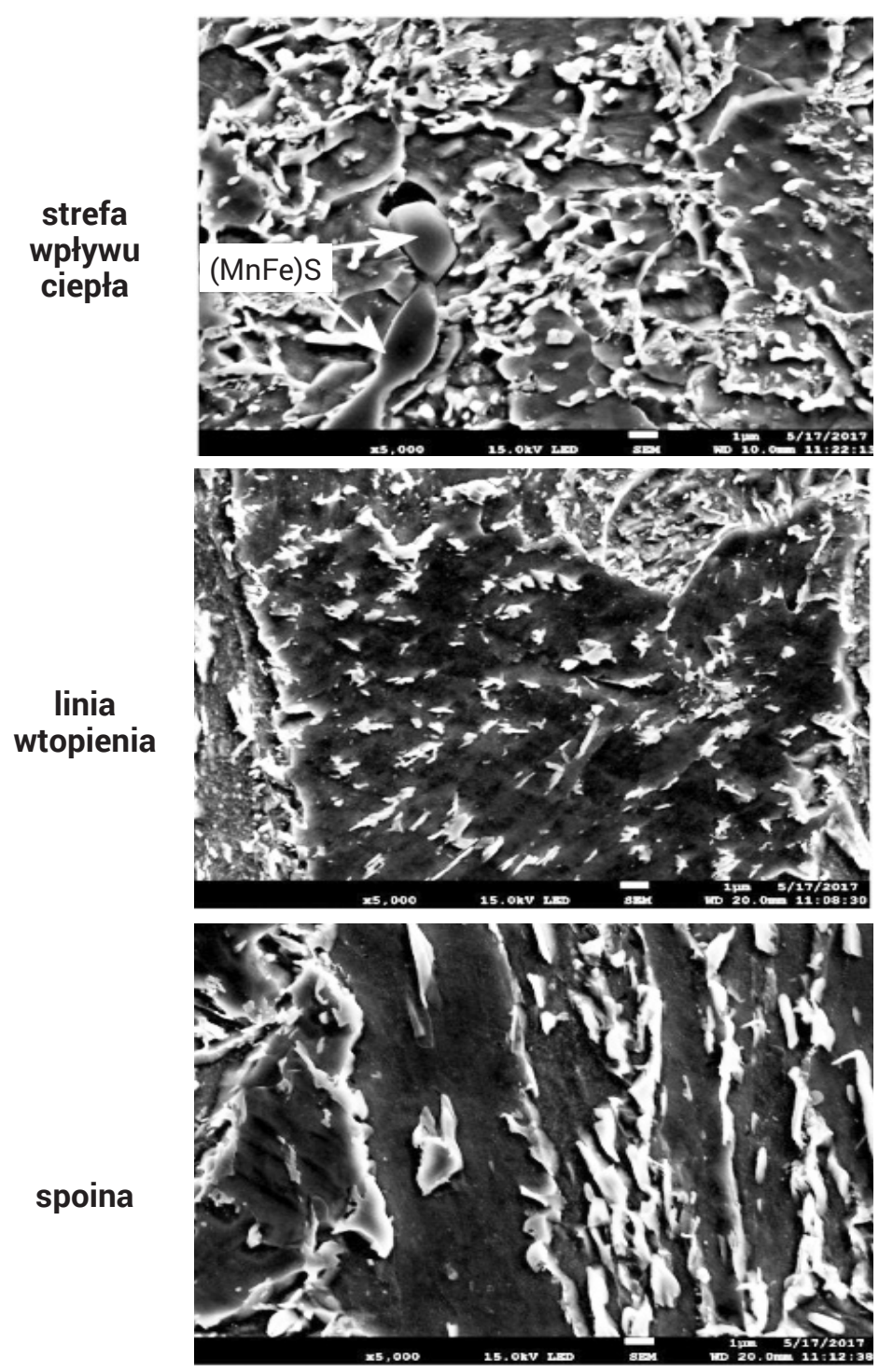

staliwo z dodatkiem MZR
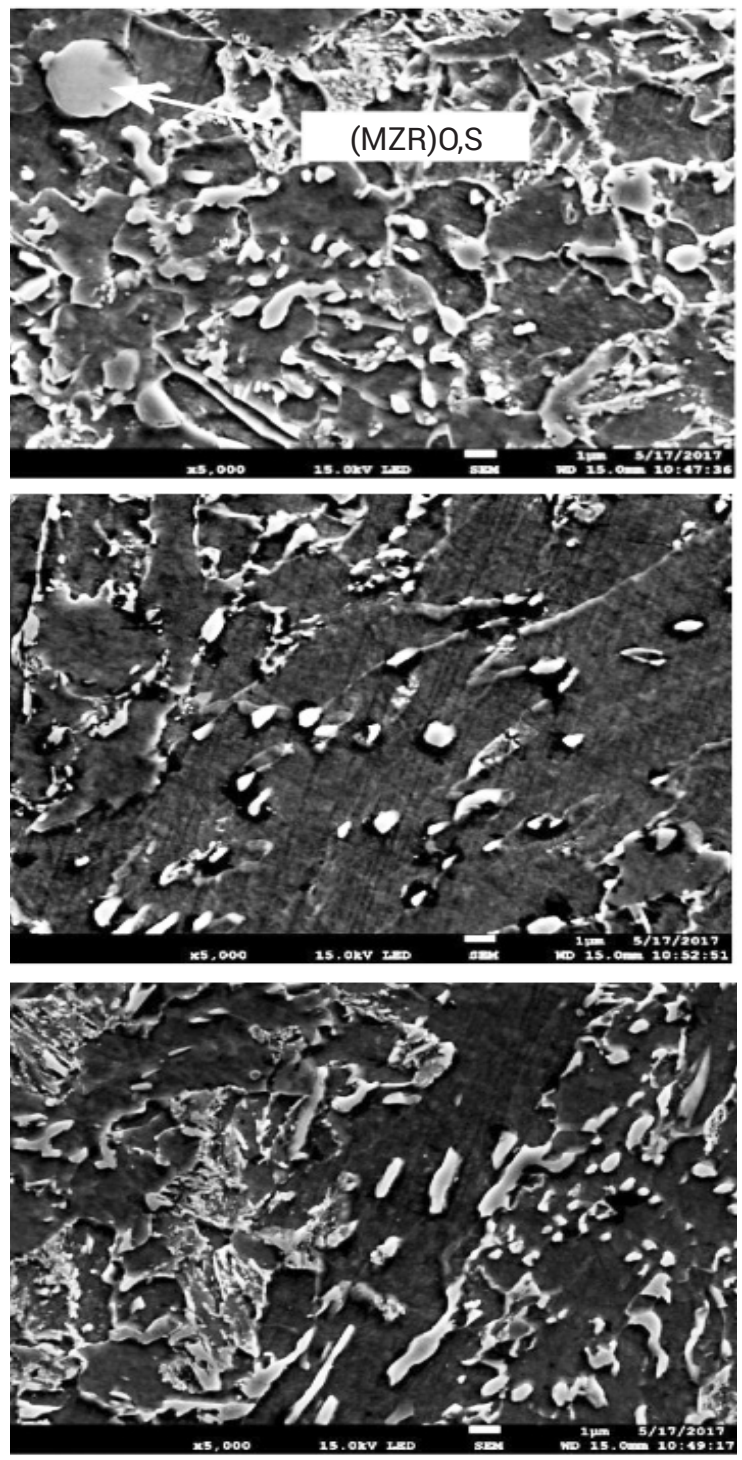

Rys. 9. Mikrostruktura złączy ze staliwa G17CrM05-5

Fig. 9. Microstructure of G17CrM05-5 welded joints

\section{Podsumowanie}

Wprowadzenie do staliwa G17CrMo5-5 metali ziem rzadkich w postaci mischmetalu spowodowało zmianę mikrostruktury staliwa. W staliwie obserwuje się bardziej równomierną strukturę bainityczną i zmniejszenie wielkości ziarna w stosunku do staliwa niemodyfikowanego. Dla złączy obu rodzaju wytopów podczas spawania metodą TIG uzyskano złącza spawane charakteryzujące się poprawną budową. Stosując technikę spawania złączy doczołowych ściegami o małej grubości dla obu wytopów otrzymano zbliżone rozkłady twardości na przekrojach poprzecznych. Twardość poszczególnych odcinków złącza spawanego w stanie wyjściowym oraz po wyżarzaniu odprężającym nie przekracza 280 HV. W przypadku złączy ze staliwa modyfikowanego zauważalny jest wzrost twardości i udarności w strefie wpływu ciepła w stosunku do staliwa niemodyfikowanego.

\section{Literatura}

[1] Karta katalogowa zaworu zwrotnego TYP 564, www.wakmet.com.pl

[2] R. Bęczkowski, M. Gucwa: Wybrane aspekty napraw odlewów korpusów urządzeń energetycznych, Przegląd Spawalnictwa, vol. 87 (5), s. 106-109, 2015

[3] Poradnik Inżyniera Spawalnictwo Tom 1, Wydawnictwo Naukowo-Techniczne, Warszawa 2003

[4] M. Gucwa, R. Bęczkowski, M. Sobala: Spawanie złączy doczołowych rur ze staliwa G17CrMo5-5 do pracy w podwyższonej temperaturze, Przegląd Spawalnictwa, vol. 87 (10), s. 84-87, 2015

[5] M. Gajewski, J. Kasińska: Rare earth metals influence on mechanical properties and crack resistance of GP240GH and G17CrMo5-5 cast steels, Archives of Foundry Engineering, vol.9 (4), pp. 37-44, 2009.

[6] J. Kasińska: Wide-ranging influence of mischmetal on properties of G17CrMo5-5 cast steel, Metalurgija, vol. 54 (1), pp. 135-138, 2015.

[7] PN-EN ISO 21952-A Materiały dodatkowe do spawania - Druty elektrodowe.

[8] PN-EN ISO 14175:2009P Materiały dodatkowe do spawania - Gazy i mieszaniny gazów do spawania i procesów pokrewnych.

[9] PN-EN ISO 9015-1 Badania twardości prowadzone na podstawie próbek poprzecznych z metalowych złączy spawanych łukowo.

[10] PN-EN ISO 17639 Badania niszczące spawanych złączy metali - Badania makroskopowe i mikroskopowe złączy spawanych.

[11] ISO 9016:2012 Badania niszczące złączy spawanych metali - Badanie udarności - Usytuowanie próbek, kierunek karbu i badanie 